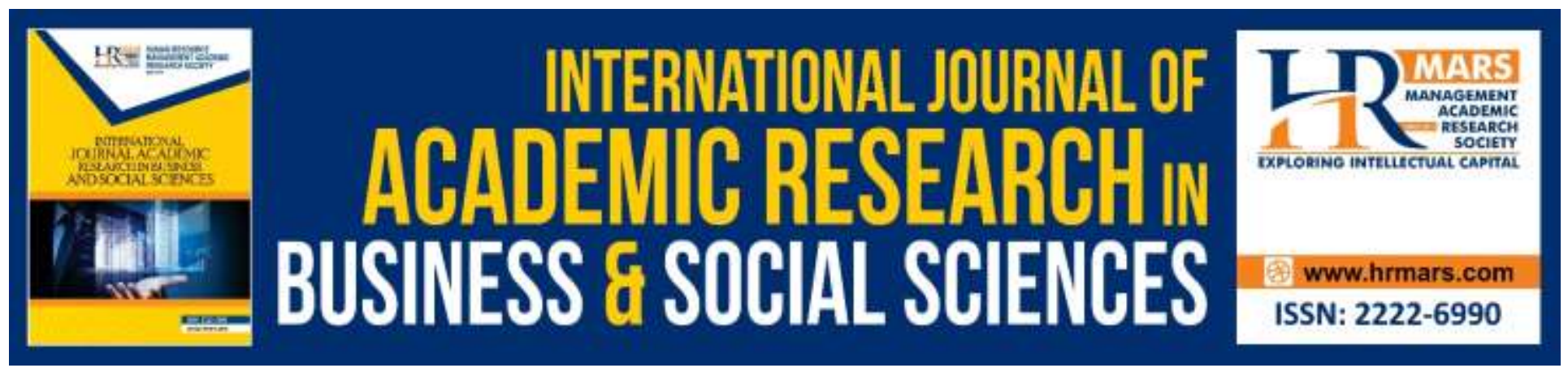

\title{
The Development of a Support System Model for School's Football Coaches in Kuala Lumpur
}

Abdul Halim b. Ismail \& Zulakbal Abdul Karim

To Link this Article: http://dx.doi.org/10.6007/IJARBSS/v10-i6/7288

DOI:10.6007/IJARBSS/v10-i6/7288

Received: 19 April 2020, Revised: 24 May 2020, Accepted: 29 May 2020

Published Online: 08 June 2020

In-Text Citation: (Ismail \& Karim, 2020)

To Cite this Article: Ismail, A. H. b., \& Karim, Z. A. (2020). The Development of a Support System Model for School's Football Coaches in Kuala Lumpur. International Journal of Academic Research in Business and Social Sciences, 10(6), 299-310.

Copyright: (c) 2020 The Author(s)

Published by Human Resource Management Academic Research Society (www.hrmars.com)

This article is published under the Creative Commons Attribution (CC BY 4.0) license. Anyone may reproduce, distribute, translate and create derivative works of this article (for both commercial and non-commercial purposes), subject to full attribution to the original publication and authors. The full terms of this license may be seen

at: http://creativecommons.org/licences/by/4.0/legalcode

Vol. 10, No. 6, 2020, Pg. 299 - 310

http://hrmars.com/index.php/pages/detail/IJARBSS

JOURNAL HOMEPAGE

Full Terms \& Conditions of access and use can be found at http://hrmars.com/index.php/pages/detail/publication-ethics 


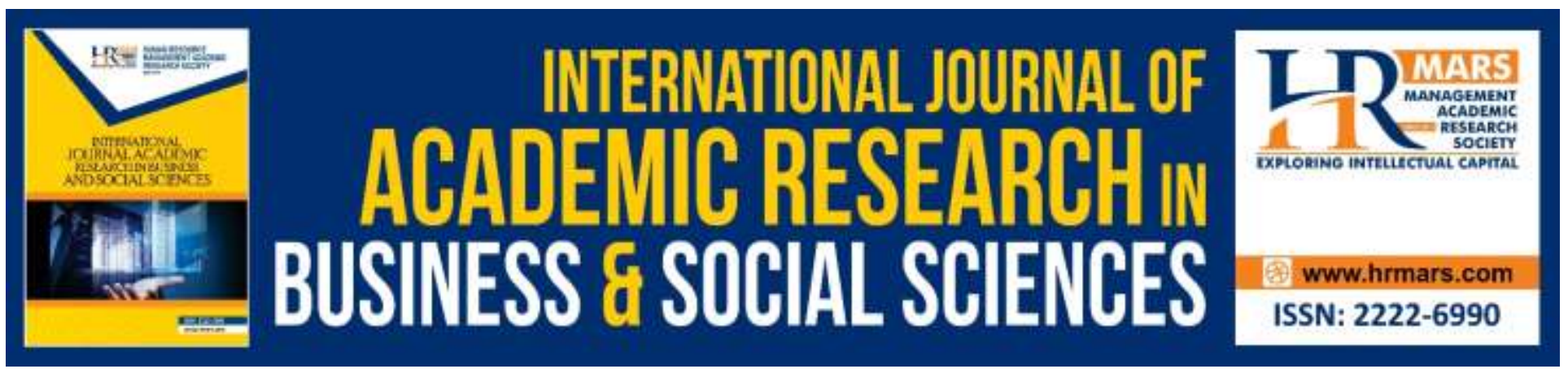

\title{
The Development of a Support System Model for School's Football Coaches in Kuala Lumpur
}

\author{
Abdul Halim b. Ismail \& Zulakbal Abdul Karim \\ Faculty of Sports Science and Coaching, Sultan Idris Education University, Tanjong Malim, Perak, \\ Malaysia \\ Email: ctevez_80@yahoo.com,zulakbal@fsskj.upsi.edu.my
}

\begin{abstract}
This research aims to identify the challenges or constraints faced by coaches among teachers in Kuala Lumpur directly involved in grassroots and youth football development programs in schools. As a result of these concerns, a model of interpersonal support system was developed to help teachers in the school become more capable and qualified coaches. This research uses qualitative research methods based on Grounded Theory approach as suggested by Strauss \& Corbin (2008; 1998; 1990). This study takes approximately one year from July 2018 to October 2019 to complete. A total of 10 participants were used in this research to obtain preliminary information or data used by researcher in building this support system model. The data obtained was determined by the level of Saturation of Information that occurred when the interview with participants were found to be unable to present any new data compared to the previous study participants. Secondary data were obtained through analysis of observations and field studies and analysis of supporting documents related to this research. Data obtained from interview, observation and field studies and related documents were analyzed using Strauss \& Corbin $(2008 ; 1998 ; 1990)$ coding data analysis. In this study, there are challenges or constraints for coaches among teachers to carry out football coaching tasks at the grassroots and youth levels in schools. In addition, this study also clarified the need to support football coaches among teachers to overcome the challenges they faced. As a result, this research successfully suggested the existence of a resource center and management of coaches among teachers in Kuala Lumpur based on the Football Coach Support System Model.
\end{abstract}

Keywords: Football, Coach, Teacher, Challenge, Support System, Grassroots and Youth.

\section{Introduction}

Football is very popular and potentially had an impact on huge number of human human life as players, coaches and fans alike, to prove that statement, I present herewith the figures and statements. At the FIFA World Cup in Russia 2018, the total number of spectators at the stadium was reported to be 3,031,768 million and 47,371 thousand for one match (Fédération Internationale de Football Association, 2018). Football is the number one sport in the world and it is also the number one sport in Malaysia (Ministry of Youth and Sports, 2013). Various football tournaments are organized around the ages from school to world level. In Malaysia, organized youth football 
tournaments aim to produce as many quality players as possible and bring the challenge of Malaysian teams to the world stage in the future. From eight, nine, 10, 11 and 12 years old to the under 13 and 17 years old categories organized by the Ministry of Youth and Sports (KBS) under the supervision of the National Football Development Program (NFDP). While at the school level, regional, district and state level national and national tournaments are held annually for 15 and 18 years old players organized by the Malaysian Schools Council (MSSM) under the Ministry of Education Malaysia (MOE). At national level regulated by Football Association of Malaysia (FAM), the tournament involves state football associations throughout Malaysia such as the Youth Cup, FAM League, Malaysian Premier League and Malaysian Super League.

The popularity of world football is inspiring all walks of life in Malaysia, regardless of gender, race and religion to participate in football whether playing or at least knowing about football. The Malaysian government is concerned about football, making this sport one of the nation's programs through the NFDP. Various implementation plans are planned, as well as football programs of all ages created to ensure that football continues to thrive in Malaysia. Schools are an important institution in identifying the early talents of Malaysian children in the sport of football. According to Husin, Megat, Kamaluddin, Rahmad (2017) school is a social organization consisting of a group of people performing structured tasks to achieve shared goals. According to Zulakbal (2016), there are about 9,930 professionally registered players and 575,000 unregistered players in Malaysia (National Football Development Program, 2014). Meanwhile, the coaching staffs of 108 were placed at District Training Centers (PLD), 70 at State Sports School (SSN) and 15 at Malaysian Sports School (SSM). Most of the coaches assigned to all PLD and State Sports Schools SSN are teachers while at SSM, teachers are appointed as assistant coaches to professional coaches appointed by KBS.

After the implementation of the program since 2014 in the first phase, there have been some challenges or obstacles especially the coaching factor involving teachers. As experienced researchers in this area see some improvements made, problems still arise, such as the burden of the right job as a teacher, training time, training space, coach knowledge resources and so on. Therefore, this research will look at issues of challenges and concerns in addition to identifying the effectiveness of a coach who is a coach under NFDP and subsequently proposing a suitable and ideal model for providing support system to coaches football among teachers to ensure the effectiveness of the field of coaching among teachers at school and at the grassroots and youth level.

\section{Objectives}

\section{General purpose}

1. To identify challenges and constraints of football coaches among teachers are facing and the support system needs, necessity and welfare

Specific purpose

1. Develop a model to provide support system for teachers who serve as PLD and SSN football coaches by identifying support system from football-related governing bodies

\section{Literature Review}

Researcher have reviewed the literature previously reviewed by other researchers on the challenges or constraints faced by coaches and teachers as well as research on coach support system among teachers using qualitative research through the field theory Grounded Theory. 
INTERNATIONAL JOURNAL OF ACADEMIC RESEARCH IN BUSINESS AND SOCIAL SCIENCES

Vol. 10, No. 6, June, 2020, E-ISSN: 2222-6990 @ 2020 HRMARS

Hamidreza (2013) conducted a study on coach leadership style, sports commitment to the satisfaction of Iranian high school football players. His findings indicate that there is a positive relationship between coach leadership style, sports commitment and football player satisfaction. Improved leadership style and satisfaction will enhance players' commitment to the sport.

The very limited and inadequate training facilities for coaches among teachers to conduct training sessions are also widely discussed by many. According to Lim Yoke Peng (2004) most schools do not have equipment facilities despite the introduction of the National Physical Fitness Test (UKJK). In addition, Kubayi, Coopoo, and Morris-Eyton (2015) found that in their study in South Africa, the challenge posed by coaches was lack of training resources. Previous studies by Surujlal and Nguyen (2011) found that lack of resources to implement training was considered a major challenge experienced by sports coaches.

Zulakbal (2016) describes the development of coaching as professional careers such as doctors, engineers and so on which relies heavily on continuous learning. In the current study, sports coaches discuss the many forms and types of learning that can be sources of knowledge, including informal learning, non-formal learning and formal learning. Specialty in formal accreditation and higher education is just part of the approach to enhance learning. Coaches who do not have a good grasp of a particular field can develop it through their own education in part or in planning (Zulakbal, 2016).

Zulakbal, Najib, and Ali (2018) propose to the National Football Development Program (NFDP), the Asian Football Confederation (AFC) and the Football Association of Malaysia (FAM) to create specific $A, B$ and $C$ football coaching licenses under the same category. are at the highest level and at the grassroots and youth level. These special licenses are not the same as the existing general coaching licenses but the grassroots and youth licenses focus more on coaches at the grassroots and youth level training young players with a syllabus or football coaching module suitable for training young footballers especially in school and football academy.

Thelwell, Weston, Greenlees, and Hutchings (2008) argue that because of the variety of roles that coaches have to play they have to take on the challenges of the technical, physical, organizational and psychological aspects of their environment. According to Norashid and Hamzah (2014), overall, the level of academic workload among teachers in schools is high especially in academic and nonacademic tasks.

For the purpose of effective teaching, Faull (2008) outlined several elements that teachers need to achieve in addition to meeting the standards of physical education teachers developed based on the "Disposition Cluster Model" (DCM) developed by Faull. Hamidreza (2013) in his study was to examine the relationship between the leadership style of transforming coaches in Iranian secondary schools, sports commitment and satisfaction of Iranian high school football players and athlete satisfaction as a mediator and proposing a new coaching model using Moedl.

\section{Problem Statement}

Many people expected the best from football coaches in schools but how many of us realized on what working condition those coaches are working in all this while? Among the importance of this research is for teachers who are appointed as coaches. The development of this model can provide support for teachers to get the support of the relevant parties in football to address issues that may be challenging or impeding their performance as coaches. 
INTERNATIONAL JOURNAL OF ACADEMIC RESEARCH IN BUSINESS AND SOCIAL SCIENCES

Vol. 10, No. 6, June, 2020, E-ISSN: 2222-6990 @ 2020 HRMARS

This involves the Football Association of Malaysia (FAM) who needs to build community confidence in the ability of coaches among teachers by redefining the training curriculum for coaches and incorporating coach support elements for teachers in schools.

Further, the Ministry of Education (MOE) Sports Division needs to streamline the power of teachers, not only to teach in schools but also to become a more professional coach in terms of knowledge and implementation at the highest and competitive levels.

The National Sports Council (MSN) football unit should utilize the expertise of its teachers by engaging teachers in the 'Re tooling' program in order to help realize the objectives or goals of the National Football Development Program (NFDP).

The existence of a sports school should be $100 \%$ sporting with the objective that every student should become a professional athlete at the state and national level by making sports like football a future career.

\section{Research Methodology}

This research focuses on and describes the background, process of study design, data collection, participant selection, observation, interviews, document analysis, data analysis, and conceptual frameworks to identify issues related to teacher challenges or constraints and support system needed by teachers as football coaches. The information will be analyzed using qualitative research methods based on Grounded Theory (Strauss and Corbin 2008; 1998; 1990).

Kamarul Azmi (2012) states that qualitative research has its own form of data that differs from quantitative research. Qualitative data is in the form of interviews, observations and document analysis. In qualitative research, much of the information depends on the interview method (Patton, 2002; Chua Yan Piaw, 2006; Frankel \& Wallen, 2007; Othman Lebar, 2017). Field notes and researcher diaries are key documents that will support and validate the field work performed. Descriptive data are descriptive in the form of verbal or written statements about observable human behavior (Taylor and Bogdan, 1998). 
INTERNATIONAL JOURNAL OF ACADEMIC RESEARCH IN BUSINESS AND SOCIAL SCIENCES Vol. 10, No. 6, June, 2020, E-ISSN: 2222-6990 @ 2020 HRMARS

\section{Research Concept Framework}

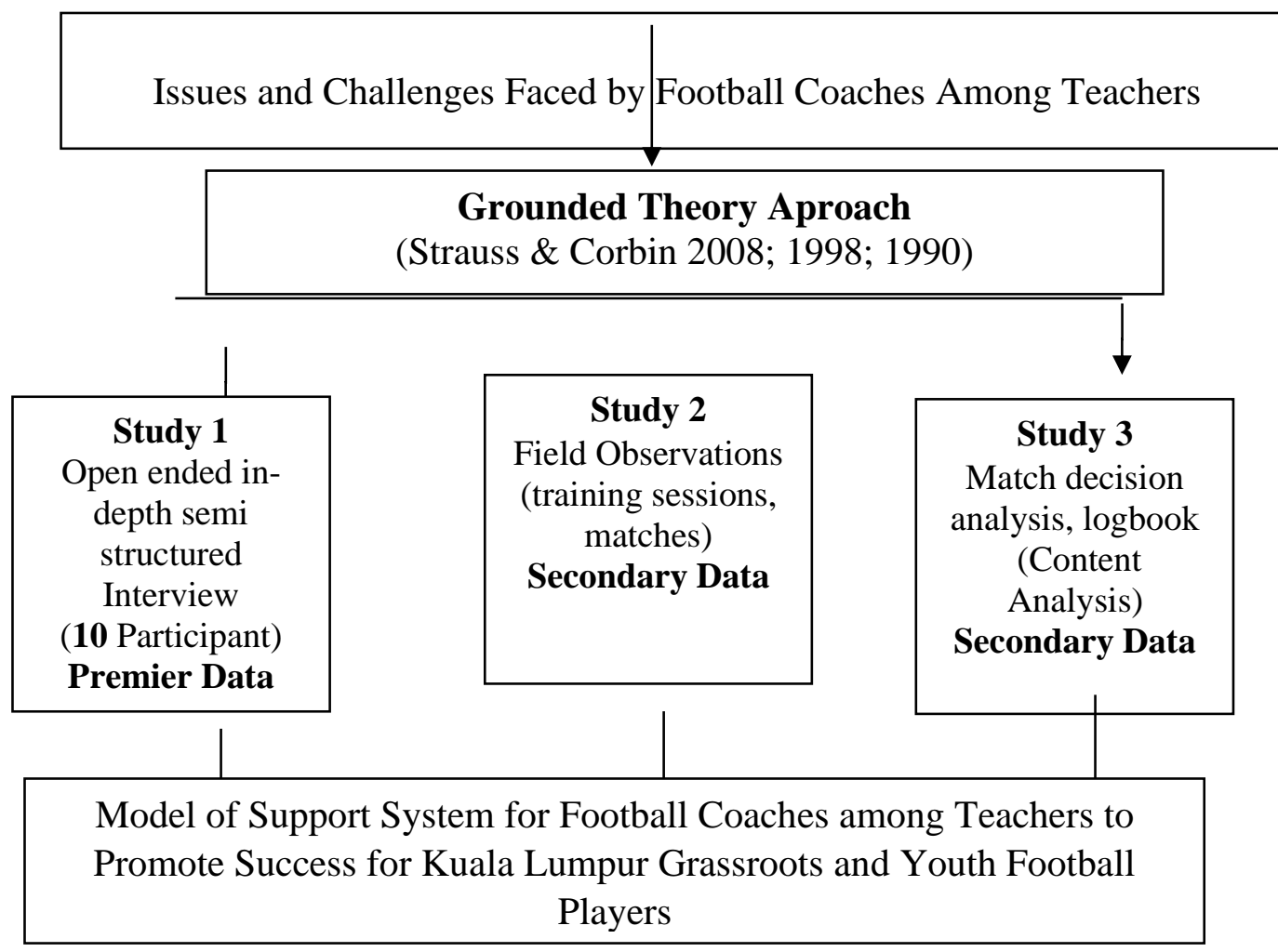

\section{Sample}

Sampling in this research refers to the process of selecting a group of individuals in a single population (Frankel \& Wallen, 2007). This research uses qualitative research by Grounded Theory. Therefore, in this research, the researcher selects the purposeful sampling or known as Purposeful Sampling (Othman Lebar, 2017). This method is also commonly used in qualitative studies. Othman Lebar (2017) also stated that in qualitative studies, selecting a sample, whether human or place has a different goal of gaining a deeper understanding of the phenomenon being studied. This is because the study selected the coach among teachers who are involved in coaching 18 to 20 players on the football team in each training center according to the age group of 13 to 17 years in District Training Center (PLD) Kuala Lumpur. During interview session, numbers of participants were determined by the degree of saturation of information which no new data seem to be emerged compared to the rest of the previous participants (Lebar, 2017; Strauss \& Corbin, 2008, 1998)

\section{Data Collection}

Qualitative research depends on the interview. The most frequently used interviews are open-ended interviews to gather information. According to Patton (2002) interviews are needed when researchers are unable to observe the behavior, feelings, or how humans try to interpret what is happening around them. My research uses a semi-structured type of semi-structured interview. According to Othman Lebar (2017) in-depth structured semi-structured interviews as open-ended questions and answers are more detailed. The questions in these open-ended interviews are predetermined but the answers to those questions are open and expandable (Patton, 2015). 
The 10 participating coaches among teachers in Kuala Lumpur were used in this research. According to Othman Lebar (2017) sample selection and data analysis are carried out continuously until the level of new information is no longer found or the information obtained is derived from previous information. This condition is known as Saturation of Information. During the interview, the researchers asked open-ended questions and the coaches were free to offer their opinions, experiences, and express their challenges in conducting the training. The interview session was transcribed and analyzed by using Grounded Theory Approach (Strauss \& Corbin, 1998).

Two types of observations are also conducted in this research, which is the first of the full observations which means that the researcher passively monitors the participants in the training by only taking field notes while observing. The second observation was made by the involvement of researchers directly and physically in the training sessions conducted by the participating participants, the football coaches at the District Training Center (PLD).

The use of documents involving specific analysis is also called content analysis. Merriam (2015) is a form of content analysis commonly used in document analysis. The third method of data collection is to analyze the various documents collected from participants, with reference to various written or typed materials.

\section{Data Analysis}

Data obtained from participants is expected to vary as knowledge, experience, work environment and trained players differ between the training centers studied. Thus, the Grounded Theory (GT) Approach by Strauss and Corbin $(1998,1990)$, that will be used in this research has a variety of constructivist reasons and bent. Coding method consists of Open Coding, Axial Coding and Selective Coding are the practice of researchers who using Grounded Theory Approach (Strauss \& Corbin, 2015; 1998; 1990).

\section{Open Coding}

Open coding involves the temporary conceptual labeling of other events and phenomena. According to Strauss and Corbin (2008) in their research, each conceptual label was derived from line-by-line analysis of interviews with transcribed participants and from the field notes of youth football training and matches at the District Training Center (PLD) Kuala Lumpur. Through open coding the researcher is able to discover over 1,002 codes in this research for identify any potential for inclusion as themes and concepts in the data obtained.

\section{Axial Coding}

According to the approach popularized by Strauss and Corbin (2008) axial coding has been defined and practiced as a category process related to the theme sub-category. A total of 39 axial codes were identified in this investigation. According to the procedure proposed by Strauss and Corbin (1998), it is necessary to identify the main categories which link to the other categories by using selective coding.

\section{Selective Coding}

Strauss and Corbin, (2008) selective coding is used to define core categories by integrating and refining the development of theory or model. The core category of this research data is identifying the support services needed by the coaches among the teachers who are the participants in the research. In this study, there were 15 selected codes that served as the basis for the researcher to 
INTERNATIONAL JOURNAL OF ACADEMIC RESEARCH IN BUSINESS AND SOCIAL SCIENCES

Vol. 10, No. 6, June, 2020, E-ISSN: 2222-6990 @ 2020 HRMARS

provide an overall picture of the research being conducted. As stated by Strauss and Corbin (1990) which integrates all categories. Interview sessions were conducted for the teachers at the school and it appeared that the main theme was the challenge and support system needed by the coaches among the teachers at the Kuala Lumpur school.

\section{Result}

All of the participants in the study provided clear insights and suggestions on what they needed to become a better coach. The challenges and barriers discussed are factors that make it difficult for them to become good coaches. Factors such as workload, unclear direction in the role of coach, limited resources and coaching education and incomplete training facilities make it difficult for them to become better coaches. Support system from stakeholders of football development program is highly sought by coaches among the teachers. Factors such as coaching education, professionalism as coaches, career pathways in coaching, training facilities and the latest football curriculum can help coach among teachers to achieve the goals set for themselves, the state team and national football.

\section{Discussion}

This research is a study to find out the issues that arise from coaches among the teachers to identify models that can assist coaches among teachers in the school and the support system needed by coaches among teachers. The data obtained from participants were divided into two themes, challenges or constraints and support system that successful helped researcher to develop a Football Coaches Support System Model among Teachers in Kuala Lumpur. The model that emerged from the Data analysis are presented in the Figure 1 as shown below. 


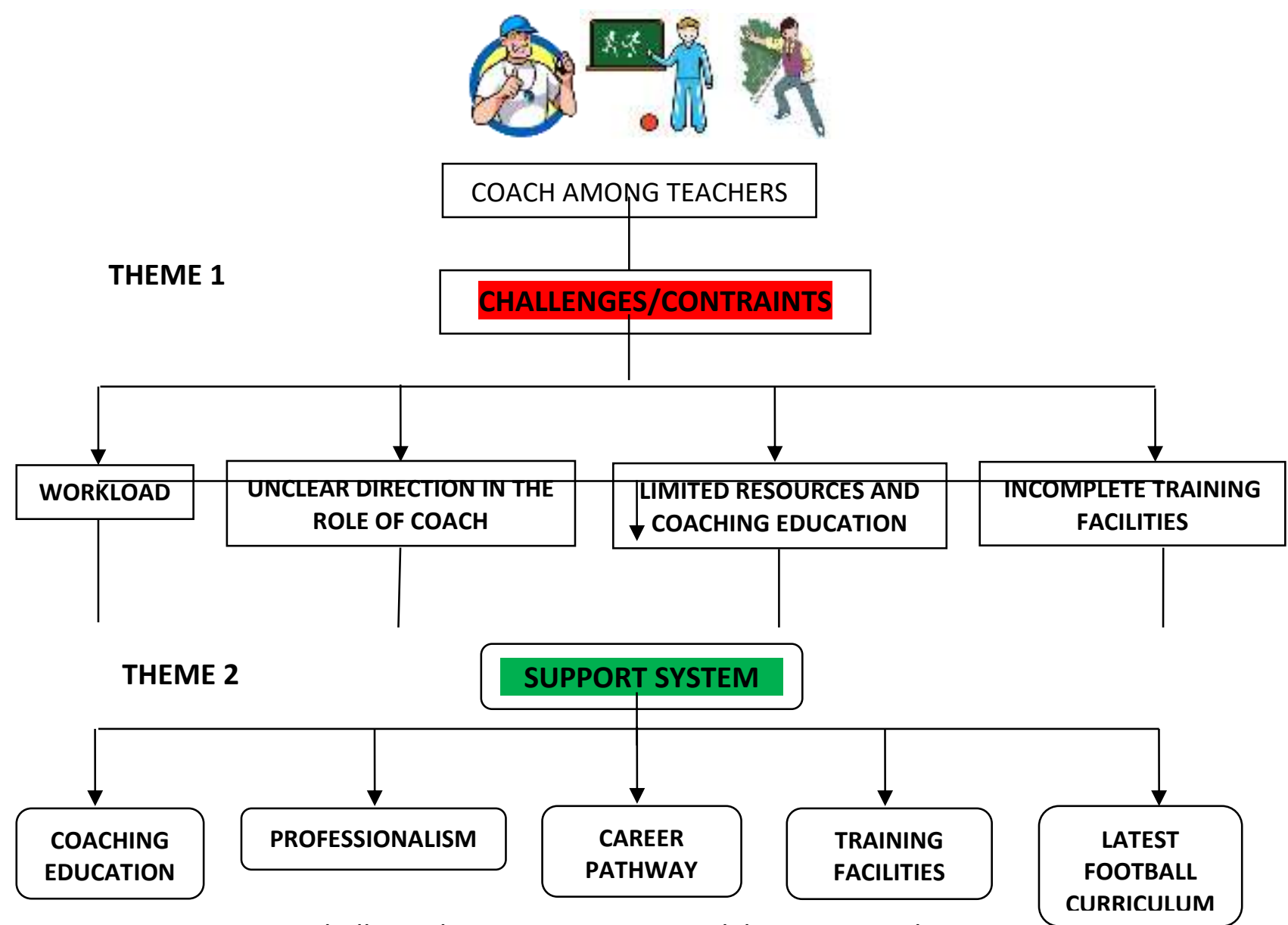

FIGURE 1: Football Coach Support System Model among Teachers in Kuala Lumpur

\section{Conclusion}

Syed, Akbal, Shukor, and Wee (2014) in their study found that the level of school environment constraint in the implementation of Physical Education teaching was high due to lack of equipment, poor equipment replacement, improper training facilities and narrow field conditions. The constraints faced by urban schools are the availability of large field areas (Sakhiyyah, 2004). A study participant from the Kuala Lumpur Sports School stated that Kuala Lumpur is the only sports school that has yet to receive allocation of sports facilities such as sports schools in other states. In connection with the previous study (Zulakbal et al. 2018), stated the need for courses, seminars, workshops, symposiums and so on to teachers among the teachers is expected and should be given consistently. Resources on football coaching at the development level and football program modules from NFDP should be located in one resource center that is accessible to all coaches, especially for teachers. In conclusion, To ensure the ability of coaches among teachers in Kuala Lumpur, footballrelated parties such as MSN, NFDP, FAM, KPM and others can provide the assistance and services needed by coaches in District Training Centers (PLD) and Kuala Lumpur Sport School in conducting coach work more effectively further enhances the confidence of outsiders about the facilities and capabilities of the Kuala Lumpur District Training Center in football at the development stage. 
INTERNATIONAL JOURNAL OF ACADEMIC RESEARCH IN BUSINESS AND SOCIAL SCIENCES

Vol. 10, No. 6, June, 2020, E-ISSN: 2222-6990 @ 2020 HRMARS

\section{Suggestion}

Countries with a strong history and teams in football such as Argentina, Brazil, Spain, France, South Korea, Japan and more certainly have a systematic and stable football association of all aspects especially in development or grassroots and youth program in order to build a strong team in national level. Researcher have suggested to establish a coaching support center for teachers can be expanded nationwide and coordinated at all levels to ensure their effectiveness and success. All coaches will have the same and comprehensive access and requirements to launch the role of coach at the grassroots and youth level. Finally, this study is intended to provide the knowledge, guidance and benefits of researchers who study football coach among teachers in future.

\section{References}

Chua, Y. P. (2006). Kaedah Penyelidikan. Malaysia: McGraw-Hill Education, Malaysia Sdn. Bhd.

Deraman, H., Ahmad, M., Daud, K., \& Shukor, R. (2017). Pelaksanaan Pengurusan Pasukan Bola Sepak Untuk Program Sukan Prestasi Tinggi Sekolah Malaysia. Jurnal Kurikulum dan Pengajaran Asia Pasifik, 5(5), 55-65.

Faull, G. A. (2008). Exceptional Teachers: A Case Study That Emphasises Dispositions When Differentiating Between Teachers. Political Science. University of Newcastle.

Franker, J. R., \& Wallen, N. E. (2007). How Design and Evaluate Research in Education. $6^{\text {th }}$ Edition. New York: The Mc Graw Hill.

Gilbert, W. D., \& Trudel, P. (2014). Learning to Coach Through Experience: Reflection in Model Youth Sport Coaches. 21(1), 16-34.

Glaser, B. G., \& Strauss, A. L. (2017). Discovery of Grounded Theory: Strategies for Qualitative Research. Ebook Publisher.

Jasmi, K. A. (2012). Metodologi Pengumpulan Data Dalam Penyelidikan Kualitatif. Kursus Penyelidikan Kualitatif Siri 1. Melaka.

Jasmi, K. A. (2012). Kesahan dan Kebolehpercayaan Dalam Kajian Kualitatif. Kursus Penyelidikan Kualitatif siri 1. 1-33. Melaka.

Kamaruzaman, S., Zahidi, A., Sukor, R., \& Wee, A. S. S. L. (2014). Faktor Kekangan Ibu Bapa dan Persekitaran Sekolah dalam Pelaksanaan Pengajaran Pendidikan Jasmani di Sekolah Rendah. Jurnal Kurikulum dan Pengajaran Asia Pasifik, Bil 2 Isu 2. Fakulti Pendidikan Universiti Malaya.

Karim, Z. A. (2016). Malaysian Football Coaches: The Key Challenges. International Journal Of Health, Physical Education and Computer Science in Sports, 24(1), 18-24.

Karim, Z. A., Ghafar, N. A. A., \& Nadzalan, A. M. (2018). The leadership Style among Football Coaches Leadership Style among Teachers in Hulu Langat District: The Implications on National Football Development Program (NFDP) in Malaysia. International Journal of Academic in Business and Social Sciences, 8(3), 551-558.

Karim, Z. A., \& Nadzalan, A. M. (2017). Malaysia Football Coaches. Development Characteristics International. International Journal of Academic Research in Business and Social Sciences, 7(9), 305-312.

Karim, Z. A., \& Razak, N. (2018). Lesson Learned from Coaches of Malaysia National Football Development Programme (NFDP) Preferred Career Development Pathway and Accredited Coaching Course. International Journal of Academic in Business and Social Sciences, 8(6), 1069-1082.

Karim, Z. A., Razak, A. N. A., \& Nadzalan, A. M. (2018). Designing Model of Career Path Development for National Football Development Programme (NFDP): Direction, Issues, Challenges and 
INTERNATIONAL JOURNAL OF ACADEMIC RESEARCH IN BUSINESS AND SOCIAL SCIENCES

Vol. 10, No. 6, June, 2020, E-ISSN: 2222-6990 @ 2020 HRMARS

Source of Knowledge that Influence and Develop Coaching Expertise Level. International Journal of Academic Research in Business and Social Sciences, 8(3), 542-550.

Kassim, M. (2014). Relation Between Knowledge of Coaching and Behaviour of Football Coaches. Centre for Coaching Science, Universiti Pertahanan Nasional Malaysia. Zulfaqar Int. J. Def. Sci. Eng. Tech. Vol.1, 43-51.

Khoo, K. K. (2017). I, KKK: The Autobiography of a Historian. Kala Publishers Sdn Bhd.

Kubayi, N. A., Coopoo, Y., \& Morris-Eyton, H. F. (2015). Challenges Faced by Sport Coaches in South Africa. African Journal for Physical, Health Education, Recreation and Dance (AJPHERD) Volume 21(3:1), September 2015, pp. 724-732.

Lebar, O. (2017). Penyelidikan Kualitatif: Pengenalan Kepada Teori dan Method. 2nd ed. Penerbit: Universiti Pendidikan Sultan Idris.

Lim, Y. P. (2004). Reka Cipta Alat "Tread mill" Bagi Ujian Kecergasan Jasmani Kebangsaan (UKJK) Untuk Menguji Daya Tahan Kardiovaskular. 24-28.

Merriam, S. B., \& Tisdell, E. J. (2015). Qualitative Research. A Guide to Design and Implementation, 4th ed. Penerbitan Jossey Bass.

Othman, N., \& Omar, H. (2014). Bebanan Tugas dan Motivasi Pengajaran Guru di Sekolah Menengah Daerah Ranau. Jurnal Pemikir Pendidikan (Journal for Educational Thinkers) Vol. 5, pp. 35-57.

Patton, M. Q. (2015). Qualitative Research and Evaluation Method $4^{\text {th }}$ Edition. Thousand Oaks. Penerbitan Sage.

Patton, M. Q. (2002). Qualitative research and evaluation methods (3rd ed.). Thousand Oaks, CA: Sage Publications, Inc.

Rahim, S. A. (2004). Relationship between Leisure Constrains and Residential School Student Participation in Recreational Sport Activities. Universiti Putra Malaysia.

Richard, G. (2019). Football Event, Memories and Globalization. Journal Football \& Society. Vol. 20 (7-8), 903-911. Taylor \& Francis Online.

Saybani, H. (2013). Structural Equation Modelling Analysis of The Relationship Between Transformational Leadership Style of Coaches, Sports Commitment and Athletes Satisfaction Among Iranian High School Football Players. Unpublished Doc. Of Philosophy Thesis. University Putra Malaysia.

Stoszkowski, J., \& Collins, D. (2016). Sources, Topics and Use of Knowledge by Coaches. Journal of Sports Sciences, Vol. 34, No. 9, 794-802. Institute of Coaching and Performance, University of Central Lancashire, Preston, UK.

Strauss, A., \& Corbin, J. (2008). Basic of Qualitative Research Technique and Procedures for Developing Grounded Theory, 358.

Strauss, A., \& Corbin, J. (1998). Basics of Qualitative Research Techniques and Procedures for Developing Grounded Theory. Second Edition Thousand Oaks: Sage Publications.

Strauss, A., \& Corbin, J. (1990). Basic of Qualitative Research: Grounded Theory Procedures and Technique. Sage Publications Inc.

Surujlal, J., \& Nguyen, S. (2011). Motives influencing football coaching: An Empirical Study of Professional Football Coaches in South Africa. African Journal for Physical, Health Education, Recreation and Dance, September (Supplement 1), 286-296.

Taylor, S. J., \& Bogdan, R. (1998). In-depth Interviewing: Introduction to Qualitative Research Method. Thelwell, R. C., Weston, N. J. V., Greenlees, I. A., \& Hutchings, N. V. (2008). A Qualitative Exploration of Psychological-Skills Use in Coaches. The Sport Psychologist, 22, 38-53. 
INTERNATIONAL JOURNAL OF ACADEMIC RESEARCH IN BUSINESS AND SOCIAL SCIENCES Vol. 10, No. 6, June, 2020, E-ISSN: 2222-6990 @ 2020 HRMARS

Wong, G. M. (2006). The Comprehensive Guide to Career in Sports. (407).

\section{Corresponding Authors}

Abdul Halim bin Ismail \& Zulakbal Abdul Karim

Faculty of Sports Science and Coaching

Sultan Idris Education University,

Tanjong Malim, Perak, Malaysia

Email: ctevez_80@yahoo.com \&zulakbal@fsskj.upsi.edu.my 